olone may be related to inhibition of granulocyte accumulation in the lung. In addition, this study provides further evidence that the two phases of the reaction are pathogenically separable.

\section{REFERENCES}

I. Brigham KL, Powers RE, McKeen CR 1981 Methylprednisolone prevention of increased lung vascular permeability following endotoxemia in sheep. $J$ Clin Invest 67:1103

2. Chinoweth DE, Cooper SW, Hugli TE, Stewart RW, Blackstone EH, Kirklin JW 1981 Complement activation during cardiopulmonary bypass. Evidence for generation of $C_{38}$ and $C_{5,}$ anaphylatoxins. $N$ Engl $J$ Med 304:497

3. Cochrane CG, Aikin BS 1966 Polymorphonuclear leukocytes in immunologic reactions. The destruction of vascular basement membrane in vivo and in vitro. J Exp Med 124:733

4. Craddock PR, Fehr J, Dalmasso AP, Brigham KL, Jacob HS 1977 Hemodialysis leukopenia. Pulmonary vascular leukostasis resulting from complement activation by dialyzer cellophane membranes. J Clin Invest 59:879

5. Flick MR, Perel A, Staub NC 1981 Leukocytes are required for increased lung microvascular permeability after microembolization in sheep. Circ Res 48:344

6. Hammerschmidt D, White J, Craddock P, Jacob H 1979 Corticosteroids inhibit complement induced granulocyte aggregation. A possible mechanism for their efficacy in shock states. J Clin Invest 63:798

7. Heflin AC Jr, Brigham KL 1981 Prevention by granulocyte depletion of increased vascular permeability in sheep lung following endotoxemia. J Clin Invest $68: 1253$

8. Hellerqvist CG, Rojas J, Green RS, Sell S, Sundell H, Stahlman MT 1981 Studies on group B $\beta$-hemolytic streptococcus. I. Isolation and partial characterization of an extracellular toxin. Pediatr Res 15:892

9. Hong S, Levine L 1976 Inhibition of arachidonic acid release from cells as the biochemical action of anti-inflammatory steroids. Proc Natl Acad Sci USA 73:1730

10. Horn KA, Meyer WT, Wyrick BC, Zimmerman RA 1974 Group B streptococcal neonatal infection. J Am Med Assoc 230:1165

11. Jacob HS, Craddock PR, Hammerschmidt DE, Moldow CF 1980 Complement induced granulocyte aggregation. An unsuspected mechanism of disease. $\mathbf{N}$ Engl J Med 302:789

12. Johnson AR 1980 Human pulmonary endothelial cells in culture: activities of cells from arteries and cells from veins. J Clin Invest 65:841

13. Rojas J, Green RS, Hellerqvist CG, Olegard R, Brigham KL, Stahlman MT 1981 Studies on group B $\beta$-hemolytic streptococcus. II. Effects on pulmonary hemodynamics and vascular permeability in unanesthetized sheep. Pediatr Res 15:899

14. Rojas J, Larsson LF, Hellerqvist CG, Brigham KL, Gray ME, Stahlman MT 1983 Pulmonary hemodynamic and ultrastructural changes associated with Group B streptococcal toxemia in adult sheep and newborn lambs. Pediatr Res 17:1002

15. Rojas J, Larsson LE, Ogletree ML, Brigham KL, Stahlman MT 1983 Effects of cyclooxygenase inhibition on the response to group B streptococcal toxin in sheep. Pediatr Res 17:107

16. Sacks T, Moldow CF, Craddock PR, Bowers TK, Jacob HS 1978 Oxygen radicals mediate endothelial damage by complement-stimulated granulocytes. An in vitro model of immune vascular damage. J Clin Invest 61:1161

17. Schalm OW (ed) 1971 Veterinary Hematology, Ed II. Lea and Febiger, Philadelphia, pp 237-246

18. Schamer W 1976 Steroids in the treatment of clinical septic shock. Am Surg 184:333

19. Skubitz KM, Craddock PP, Hammerschmidt DE, August JT 1981 Corticosteroids block binding of chemotactic peptide to its receptor on granulocytes and cause disaggregation of granulocyte aggregates in vitro. $J$ Clin Invest $68: 13$

\title{
Inherited Lactic Acidosis: Correction of the Defect in Cultured Fibroblasts
}

\author{
PAUL R. GOODYER AND GERALD A. LANCASTER \\ Department of Nephrology [P.R.G.] and Department of Biochemical Genetics [G.A.L.], McGill University- \\ Montreal Children's Hospital Research Institute, Montreal, Quebec, Canada H3H IP3
}

\begin{abstract}
We report a case of familial lactic acidosis, lethal in the newborn period. Studies in intact fibroblasts identified a defect in the oxidative pathway of pyruvate metabolism. Although assay of pyruvate dehydrogenase on cell sonicates was not appreciably reduced, flux through the enzyme and other mitochondrial multienzyme dehydrogenases was severely impaired in intact cells. Deficient lactate conversion to carbon dioxide could be repaired by the addition to the incubation medium of electron acceptors such as methylene blue $(25 \mu \mathrm{g} / \mathrm{ml})$ or dichlorophenolindophenol $(25 \mu \mathrm{g} / \mathrm{ml})$. (Pediatr Res 18: 1144-1148, 1984)
\end{abstract}

\section{Abbreviation}

\section{PDH, pyruvate dehydrogenase}

Received January 12, 1983; accepted April 19, 1984

This work was supported by the MRC Genetics Group, the Réseau de Médecine Génétique du Québec, and the McGill University-Montreal Children's Hospital Research Institute. P. R. G. is a recipient of the McGill University-Montreal Children's Hospital Junior Scientist Award. This is Publication No. 84033 of the McGill University-Montreal Children's Hospital Research Institute.
Inherited forms of lactic acidosis have been recognized since the early 1960 s $(7,12,17)$. Recently, these disorders have been classified into errors of the gluconeogenic or oxidative pathways leading from pyruvate.

In the gluconeogenic group, lactic acidosis is accompanied by hypoglycemia and is exacerbated by fasting. The most frequent cause is deficiency of pyruvate carboxylase (EC 6.4.1.1), an intramitochondrial enzyme which can be measured in fibroblasts $(1,20)$ and amniocytes $(9,11)$ making antenatal diagnosis possible. In isolated pyruvate carboxylase deficiency, therapy has generally been unsatisfactory $(13,27)$ and prognosis is poor. When other carboxylases are affected, the disorder involves attachment of biotin to the apocarboxylase or biotin availability and may be successfully treated by pharmacologic doses of this cofactor $(22,25)$. Phosphoenolpyruvate carboxykinase (EC 4.1.1.32) may be measured in fibroblasts, but deficiencies of this enzyme associated with lactic acidosis are rare $(14,21)$. Fructose1,6-diphosphatase (EC 3.1.3.11) and glucose-6-phosphatase (EC 3.1.3.9) deficiencies are diagnosed in gluconeogenic tissues and may be managed by frequent carbohydrate feeds $(2,15,16)$.

Errors of the oxidative pathway of pyruvate metabolism are less amenable to therapy. Patients with abnormal enzymes of the 
pyruvate dẹhydrogenase complex have been treated with dichloroacetic acid (an activator of the first component), thiamine (a cofactor for the first component), lipoic acid (a cofactor for the second component), and ketogenic diets (to provide ketone bodies as an alternative energy substrate for cerebral metabolism). Blood lactate levels may be reduced, but psychomotor retardation has not been improved $(3,8,28)$. There are reports of lactic acidosis in association with defects in the electron transport chain $(6,26,29)$, but these cases are incompletely understood and were unresponsive to therapy. The patients exhibited a subacute myopathy with morphologic abnormalities of muscle mitochondria.

In the late $1960 \mathrm{~s}$, attempts were made to treat toxin-induced lactic acidosis with the redox dye, methylene blue. Some improvement was achieved for phenformin toxicity (19), but this is not a recognized therapy for the hereditary forms of lactic acidosis. In this report, we discuss the effects of methylene blue on defective lactate oxidation by fibroblasts from a patient with an inherited form of lactic acidosis.

\section{CASE HISTORY}

The proband was born at 41 weeks without complication. She was small for gestational age (body weight, $2180 \mathrm{~g}$ ) and fed poorly during the first week of life. On day 7 , she was noted to have mild metabolic acidosis and was transferred to The Montreal Children's Hospital. At that time, she was tachypneic, irritable, and hypertonic and exhibited scissoring of the lower extremities. There were no dysmorphic features, but the liver was enlarged. Initial laboratory data included: blood $\mathrm{pH}$ of $7.4, \mathrm{CO}_{2}$ tension of $22 \mathrm{~mm} \mathrm{Hg}$, bicarbonate of $14.2 \mathrm{mEq} /$ liter and an anion gap of $30 \mathrm{mEq} /$ liter.

Oral feeds were discontinued and acidosis was corrected with intravenous bicarbonate. Mild hypoglycemia $(34 \mathrm{mg} / \mathrm{dl})$ was corrected with a $15 \%$ dextrose infusion. During this period, serum amino and organic acids were measured (see Table 1) and were suggestive of a primary lactic acidosis. Urinary amino and organic acids were unremarkable except for massive elevation of lactate, $\alpha$ - and $\beta$-hydroxybutyrates, and a modest elevation of alanine. On the 15 th day of life, oral feeds of Similac-20 were begun. Within $36 \mathrm{~h}$, worsening acidosis and seizures were followed by cardiac arrest and death.

Parents were nonconsanguinous. A previous male sibling died of lactic acidosis on the 8th day of life. A subsequent female sibling is asymptomatic.

\section{MATERIALS AND METHODS}

Control cell strains were obtained from the Repository for Mutant Human Cells at the Montreal Children's Hospital Research Institute. Cultured skin fibroblasts from the proband and subsequently from the parents and a younger sibling were established from primary cultures of full thickness punch biopsies.

Table 1. Serum acids measured on day 13 of life

\begin{tabular}{lcc}
\hline & Patient & Normal values \\
\hline Organic acids* & & \\
Lactate & 300 & $(9-16)$ \\
Pyruvate & 2.2 & $(0.4-0.6)$ \\
Acetoacetate & 0.4 & $(0-32)$ \\
$\beta$-Hydroxybutyrate & 15 & $(0-3.5)$ \\
Amino acids $\dagger$ & & \\
Alanine & 0.56 & $(0.24-0.34)$ \\
Valine & 0.23 & $(0.05-0.20)$ \\
Leucine & 0.15 & $(0.05-0.10)$ \\
Isoleucine & 0.06 & $(0.03-0.045)$ \\
\hline
\end{tabular}

* Determined by GLC-MS and expressed in $\mathrm{mg} / \mathrm{dl}$.

$\dagger$ Determined by automatic amino acid analysis, and expressed in $\mathrm{mmol} / \mathrm{liter}$.
Pyruvate dehydrogenase-deficient cells were obtained from Dr. M. Batshaw (Johns Hopkins University). A pyruvate carboxylase-deficient strain was obtained from the Repository. Enzymic diagnoses on both strains were performed by Dr. B. H. Robinson (University of Toronto). The cultured cells were maintained in minimal essential medium (Gibco), supplemented with $5 \%$ fetal calf serum, $5 \%$ newborn calf serum, sodium pyruvate $(110 \mathrm{mg} /$ liter), and sodium bicarbonate $(2.24 \mathrm{~g} /$ liter $)$ in $75-\mathrm{cm}^{2}$ plastic flasks (Lux). Cells were harvested with Versene followed by trypsin and washed once with a large volume $(50 \mathrm{ml})$ of phosphate-buffered saline.

All isotopes were obtained from New England Nuclear (Montreal) and other chemicals were from Fisher Scientific (Montreal). Whole cell incubations were performed in Warburg flasks in a modifed Krebs buffer (23) without glucose with the appropriate isotope at $37^{\circ} \mathrm{C}$ (total volume, $2.0 \mathrm{ml}$ ) for $90 \mathrm{~min}$. Reactions were stopped by the addition of $9 \mathrm{~N}$ sulfuric acid $(50 \mu \mathrm{l})$ and the ${ }^{14} \mathrm{CO}_{2}$ was trapped on filter papers containing $50 \mu \mathrm{l}$ of $1 \mathrm{~N}$ potassium hydroxide. Prior to scintillation counting in Formula 963 (New England Nuclear), $0.25 \mathrm{ml}$ of water was added to the $\mathrm{KOH}$ paper. Pyruvate dehydrogenase was assayed on cell sonicates by the method of Stromme (24). Measurement of lactate and other organic acids was by gas-liquid chromatography-mass spectroscopy; amino acids were measured by automated amino acid analysis (Dionex).

\section{RESULTS}

Difficulty was encountered in establishing cultures from the proband. The medium became very acidic due to a build-up of lactate levels in excess of $11 \mathrm{mM}$ (normal value for cells grown under the same conditions was less than $3.5 \mathrm{mM}$ ). Cells growing from the explant tended to peel from the plastic Petri dishes when confluent; this same phenomenon occurred when the cells were cultured in $75-\mathrm{cm}^{2}$ plastic flasks. With more frequent feedings and a larger volume of medium, the cells grew normally.

The proband's fibroblasts exhibited a marked inability to decarboxylate $\mathrm{L}-\left[1-{ }^{14} \mathrm{C}\right]$ lactate $(1 \mathrm{mM})$; activity was consistently below $10 \%$ of the lowest control value (Table 2). Fibroblasts from both parents and an unaffected sibling gave normal values for the production of carbon dioxide from L-lactate.

There was considerable interstrain variation in lactate metabolism by normal fibroblasts, but low variation within individual strains. The variation was not related to age (1 month-35 years), sex of donor, or the number of doublings in culture (at least up to 30 doublings).

Defective lactate metabolism could not be attributed to defi-

Table 2. Conversion of $\mathrm{L}-\left[1-{ }^{14} \mathrm{C}\right]$ lactate to ${ }^{14} \mathrm{CO}_{2}$ by intact fibroblasts

\begin{tabular}{|c|c|}
\hline Strain & $\begin{array}{c}\text { Conversion* } \\
\left(\mathrm{nmol}{ }^{14} \mathrm{CO}_{2} / \mathrm{mg} \text { protein } / \mathrm{h}\right)( \pm \mathrm{SEM})\end{array}$ \\
\hline Control 1 & $15.1 \pm 2.5(15)$ \\
\hline 2 & $14.6 \pm 1.1(14)$ \\
\hline 3 & $20.1 \pm 1.8(15)$ \\
\hline 4 & $17.0 \pm 1.3(7)$ \\
\hline 5 & $30.0 \pm 2.2(16)$ \\
\hline 6 & $11.2 \pm 0.9(4)$ \\
\hline 7 & $18.5 \pm 0.2(3)$ \\
\hline Mean & $18.1 \pm 2.3$ \\
\hline Range & $11.2-30.0$ \\
\hline Pyruvate carboxylase deficiency & $18.1 \pm 1.9(3)$ \\
\hline Proband & $1.0 \pm 0.2(30)$ \\
\hline Sibling & $45.9 \pm 1.8(4)$ \\
\hline Mother & $14.4 \pm 1.0(4)$ \\
\hline Father & $13.4 \pm 1.5(4)$ \\
\hline
\end{tabular}

* Number of experiments in parentheses. 
ciency of lactate dehydrogenase activity since pyruvate $(1 \mathrm{mM})$ decarboxylation by the proband's fibroblasts was undetectable and alanine $(1 \mathrm{mM})$ conversion to carbon dioxide was similarly depressed, i.e. $13 \%$ of controls (see Table 3). All of these substrates enter pathways of oxidative metabolism in the form of pyruvate. On the other hand, substrates which enter the tricarboxylic acid cycle without being converted to pyruvate (e.g. [2,3$\left.{ }^{14} \mathrm{C}\right]$ succinate and $\mathrm{L}-\left[\mathrm{U}-{ }^{14} \mathrm{C}\right]$ aspartate) were oxidized to ${ }^{14} \mathrm{CO}_{2}$ at normal rates by the proband's fibroblasts (Table 3 ).

Oxidation of pyruvate requires entry of this substrate into the mitochondrion and decarboxylation via the multienzyme complex, PDH. PDH regulation is accomplished by a process of activation-deactivation involving phosphorylation of the first component. The kinase which inactivates PDH can be inhibited by dichloroacetic acid (5). When the patient's fibroblasts were exposed to dichloroacetic acid $(0.5 \mathrm{mM})$, a slight stimulation ( $200 \%$ of basal value) of lactate oxidation was noted but activity remained far below the lower limit of control.

Assay of PDH activity of the proband's fibroblasts showed near-normal activity $[19.5 \pm 3.1$ (SEM) $\mathrm{nmol} \mathrm{CO} 2 / \mathrm{mg}$ protein/ $\mathrm{h}$ or $82 \pm 9 \%$ of three control strains]. However, this in vitro assay is performed at saturating concentrations of cofactors and may not reflect activity in the intact cell. To test the possibility that in vivo PDH activity was deficient in the proband due to an abnormality of cofactor availability, we examined fibroblast utilization of other substrates which are oxidized via separate multienzyme dehydrogenases, i.e. glutamate and leucine. As can be seen from Table 3 , decarboxylation of these substrates was markedly reduced.

Several attempts were made to correct lactate oxidation in intact fibroblasts by supplementing the cells with cofactors involved in the multi-enzyme dehydrogenases.

Thiamine supplementation. The first component of the PDH complex, pyruvate decarboxylase (EC 4.1.1.1), requires thiamine pyrophosphate as a cofactor. Confluent control and proband cells were cultured for $24 \mathrm{~h}$ in the presence or absence of 0.7 $\mathrm{mM}$ thiamine. Cells were then harvested and challenged with $\mathrm{L}-$ $\left[1-{ }^{14} \mathrm{C}\right]$ lactate in the usual modified Krebs buffer with added thiamine $(0.7 \mathrm{mM})$. Table 4 shows that thiamine supplementation made no difference to the ability of proband cells to oxidize lactate to $\mathrm{CO}_{2}(p<0.05)$.

Lipoic acid supplementation. The second component of the PDH complex, lipoate acetyltransferase (EC 2.3.1.12), is a lipoic acid-dependent enzyme which transfers the two-carbon unit derived from pyruvate to coenzyme A. Fibroblasts from the proband and control were treated at confluence for $18 \mathrm{~h}$ with lipoic acid $(0.1 \mathrm{mM})$ added to the culture medium; no improvement of lactate oxidation was noted (Table 4).

Electron acceptor supplementation. The third component of the PDH complex, lipoamide dehydrogenase (EC 1.6.4.3), is required to reoxidize the lipoic acid of lipoate acetyltransferase. Oxidizing equivalents derived from the electron transport chain are linked to this step via redox reactions involving FAD and NAD. To test for a possible defect in electron transfer in the proband's cells, incubation medium was supplemented with a variety of electron acceptors (methylene blue, nitroblue tetrazolium, dichlorophenolindophenol, and potassium ferricyanide) during substrate oxidation assays. Although nitroblue tetrazolium and potassium ferricyanide had no effect on the patient's cells, methylene blue $(25 \mu \mathrm{g} / \mathrm{ml})$ and dichlorophenolindophenol $(25 \mu \mathrm{g} / \mathrm{ml})$ produced dramatic repair of lactate oxidation (12 to 13-fold stimulation above basal values). Methylene blue was chosen for further studies since it has been used clinically (10).

Figure 1 shows that the addition of methylene blue increased conversion of $\mathrm{L}-\left[1-{ }^{14} \mathrm{C}\right]$ lactate to ${ }^{14} \mathrm{CO}_{2}$ by the proband's cells, but had no significant effect on activity of control fibroblasts. Methylene blue did not produce spontaneous decarboxylation of lactate in the absence of cells, nor did it stimulate the deficient lactate oxidation in a fibroblast strain derived from a patient with documented pyruvate decarboxylase deficiency. Alanine oxidation to $\mathrm{CO}_{2}$ by the proband's cells was similarly increased (14-fold) upon addition of methylene blue. Under the same conditions, alanine oxidation by control cells was significantly inhibited. Oxidation of leucine and glutamate was deficient in the proband's cells; modest improvement was noted in the presence of methylene blue (4-fold and 2-fold, respectively).

\section{DISCUSSION}

In this report, we describe a case of inherited lethal lactic acidosis presenting in the newborn period. The pattern of inheritance appears to be autosomal recessive since the proband was female and an older male sibling died in the newborn period with persistent elevated blood lactate. The nonconsanguinous parents were clinically unaffected, and their fibroblasts converted lactate to carbon dioxide in the low normal range. Considering

Table 3. Conversion of various substrates to ${ }^{14} \mathrm{CO}_{2}$ by intact fibroblasts*

\begin{tabular}{llccc}
\hline \multicolumn{1}{c}{ Substrate } & \multicolumn{1}{c}{ Proband } & Control 1 & Control 2 & Control 3 \\
\hline L- $\left[\mathrm{U}-{ }^{14} \mathrm{C}\right]$ Alanine & $0.4 \pm 0.1(6)$ & $3.1 \pm 0.3(3)$ & $2.8 \pm 0.1(3)$ & $4.0 \pm 0.1(3)$ \\
{$\left[1-{ }^{14} \mathrm{C}\right]$ Pyruvate } & Not detectable $(4)$ & $42.8 \pm 2.9(4)$ & $38.7 \pm 0.3(3)$ & \\
{$\left[2,3-{ }^{14} \mathrm{C}\right]$ Succinate } & $0.28 \pm 0.5(3)$ & $0.31 \pm 0.02(3)$ & $0.51 \pm 0.02(4)$ & $0.23 \pm 0.02(4)$ \\
L- $\left[\mathrm{U}-{ }^{14} \mathrm{C}\right]$ Aspartate & $5.3 \pm 1.0(3)$ & $1.7 \pm 0.6(4)$ & $0.94 \pm 0.1(4)$ & $4.0 \pm 0.1(4)$ \\
L[1- $\left.1{ }^{14} \mathrm{C}\right]$ Glutamate & $3.0 \pm 0.2(16)$ & $8.8 \pm 0.3(6)$ & $9.0 \pm 0.5(6)$ & $15.5 \pm 0.3(4)$ \\
L[1-14 C]Leucine & $0.16 \pm 0.05(4)$ & $7.28 \pm 0.18(4)$ & $5.72 \pm 0.66(4)$ & $4.45 \pm 0.29(4)$ \\
\hline
\end{tabular}

* Substrates were incubated at $1 \mathrm{mM}$ except for succinate and leucine which were $0.1 \mathrm{mM}$. Values are expressed as $\mathrm{nmol} \mathrm{CO} / \mathrm{mg}$ protein/h and are \pm SEM. Number of experiments in parentheses.

Table 4. Attempts to rescue lactate oxidation in proband's fibroblasts with vitamin supplementation

\begin{tabular}{cccc}
\hline Strain & $\begin{array}{c}\text { Growth } \\
\text { condition }\end{array}$ & $\begin{array}{c}\text { Incubation } \\
\text { condition }\end{array}$ & $\begin{array}{c}\text { Lactate } \\
\text { oxidation* }\end{array}$ \\
\hline Control & $0.7 \mathrm{mM}$ thiamine & $0.7 \mathrm{mM}$ thiamine & $14.5 \pm 1.5(6)$ \\
& & $0.7 \mathrm{mM}$ thiamine & $18.8 \pm 1.4(6)$ \\
Proband & $0.7 \mathrm{mM}$ thiamine & $0.7 \mathrm{mM}$ thiamine & $0.2(6)$ \\
Control & & $0.7 \mathrm{mM}$ thiamine & $17.9 \pm 0.1(6)$ \\
& $0.1 \mathrm{mM}$ lipoic acid & & $1.9 \pm 2.9(4)$ \\
Proband & & & Not detectable (4) \\
& $0.1 \mathrm{mM}$ lipoic acid & $1.0 \pm 0.2(30$ & \\
\hline
\end{tabular}

\footnotetext{
* Addition of thiamine or lipoic acid had no statistically significant stimulation of lactate oxidation (nmol $\mathrm{CO}_{2} / \mathrm{mg} \mathrm{protein} / \mathrm{h}$ ). Number of experiments in parentheses.
} 


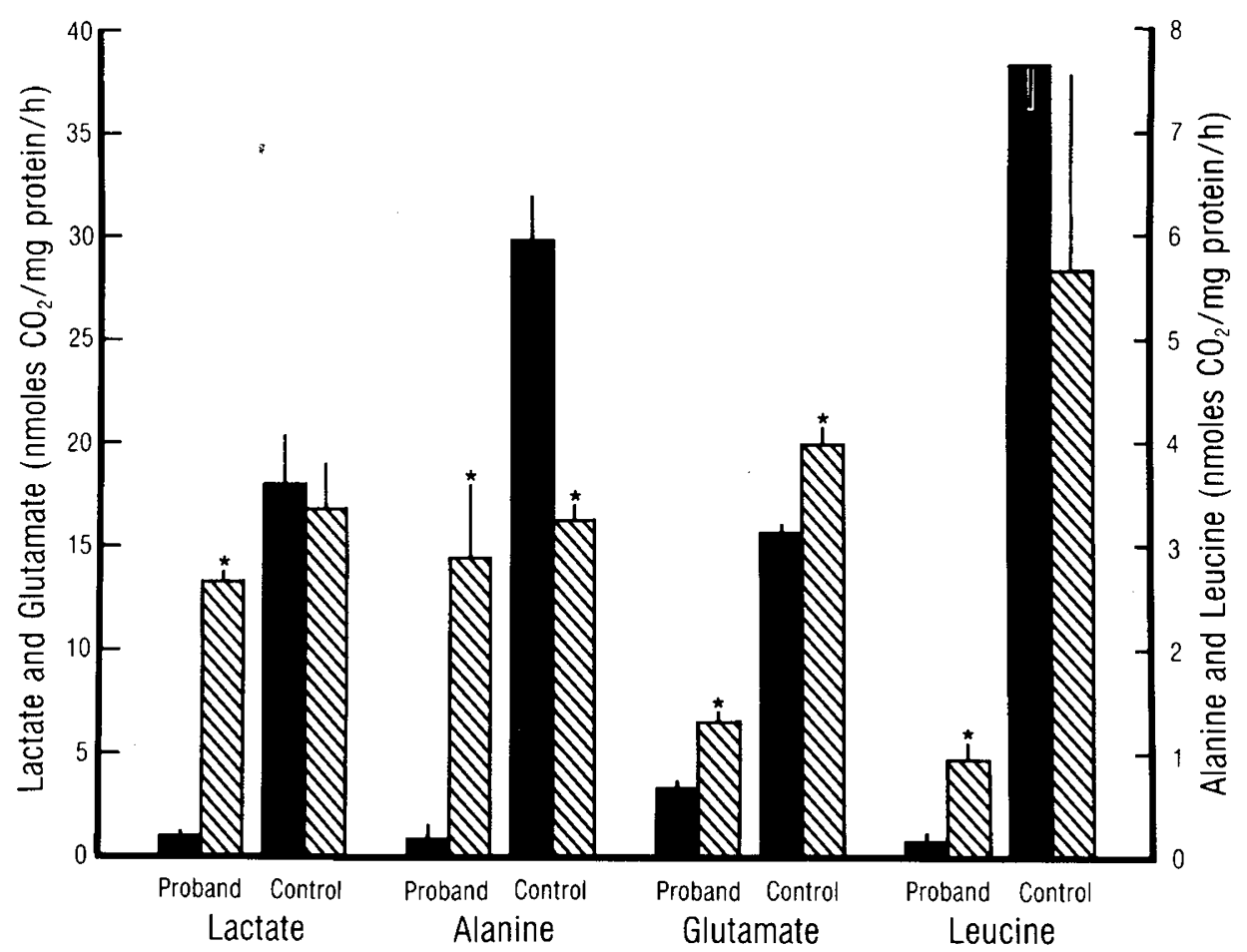

Fig. 1. In the proband's fibroblasts, methylene blue, $25 \mu \mathrm{g} / \mathrm{ml}$ (hatched bars), increased oxidation of all substrates significantly $(p<0.01$ indicated by an asterisk) compared to basal levels (solid bars). In controls, stimulation was not observed except for glutamate.

the wide range of normal activity and the distance of the assay from the primary gene defect, this may represent the heterozygous state.

In a series of 40 cases, Robinson et al. (21) were able to identify metabolic abnormalities in fibroblasts derived from 14; their studies usually involved direct measurement of enzyme activity in cell extracts. The metabolic basis of lactic acidosis in our patient could not be diagnosed from clinical parameters, but her intact fibroblasts clearly expressed the defect, causing lactate accumulation and consequent acidification of the growth medium. This observation and initial studies demonstrating defective conversion of lactate, pyruvate, and alanine to carbon dioxide suggested an error in oxidative metabolism of pyruvate. Fibroblasts from patients with primary gluconeogenic disorders convert lactate to carbon dioxide at normal rates (e.g. the strain with pyruvate carboxylase deficiency cited in Table 2 ).

When the proband's fibroblasts were challenged with substrates such as aspartate and succinate, which enter the tricarboxylic acid cycle independent of multienzyme dehydrogenase complexes, activity was normal. This finding indicated that the disorder of pyruvate was not an artifact of dying cells.

Activity of the PDH complex was measured in fibroblast extracts from the proband. The modest reduction in activity compared to control strains could not explain the severely deficient utilization of pyruvate by intact cells. To test the hypothesis that cofactor availability was abnormal and rate-limiting in intact fibroblasts, we attempted to correct lactate oxidation by supplementing the cells with high levels of relevant cofactors. Although thiamine and lipoate were without effect, addition of certain artificial electron acceptors (methylene blue and dichlorophenolindophenol) produced dramatic correction of lactate oxidation to levels approaching the lower limits of normal. Methylene blue had a specific effect on the proband's cells and did not augment lactate or alanine conversion to carbon dioxide in normal or PDH-deficient fibroblasts.

As can be seen by Figure 1, conversion of glutamate and leucine were deficient in the proband's cells, and significant stimulation was achieved by methylene blue supplementation. Branched chain amino acids were modestly elevated in the patient's serum (Table 1); this sample was drawn during the initial hospital course with high glucose ( $15 \%$ glucose-containing intravenous solution), zero protein intake. At these levels of branched chain amino acids, an elevation of the corresponding ketoacids would not be expected in either serum or urine (18).

To explain the effect of methylene blue on the proband's fibroblasts, we hypothesized that coupling of lipoamide dehydrogenases to the electron transport chain or intramitochondrial electron acceptor availability was abnormal, resulting in an accumulation of reduced pyridine dinucleotides. Such an abnormality in cellular redox state would explain the abnormally high lactate to pyruvate and $\beta$-hydroxybutyrate to acetoacetate ratios observed in the patient's serum. Furthermore, intramitochondrial accumulation of reduced pyridine dinucleotides would explain: 1) the defect in flux of pyruvate through PDH observed in the intact cell, but not in the cell sonicate; and 2) the deficient whole-cell oxidation of glutamate and leucine, substrates which utilize similar lipoamide dehydrogenase-containing multienzyme complexes.

Inherited forms of lactic acidosis presenting in the neonatal period are usually lethal within a few weeks of onset, leaving little time for enzymic diagnosis. Therefore, affected infants are often challenged with a series of potentially therapeutic drugs based on reports of correctable metabolic errors (such as biotinresponsive forms of multiple carboxylase deficiency). Although hemolysis has been reported with use of methylene blue in certain clinical situations (4), it has been successfully employed in long term oral therapy of inherited methemoglobinemia (10). In view of its beneficial in vitro effects in our case, we propose that methylene blue be included among the trial therapies for newborns with life-threatening congenital lactic acidosis.

Acknowledgments. We would like to thank Dr. C. R. Scriver (deBelle Laboratory, MCH) for useful discussions and Dr. O. Mamer (Mass-Spectrometry Unit, McGill University) for determination of organic acids.

\section{REFERENCES}

1. Atkin BM, Utter MF, Weinburg MB 1979 Pyruvate carboxylase and phosphoenolpyruvate carboxykinase activity in leukocytes and fibroblasts from a patient with pyruvate carboxylase deficiency. Pediatr Res 13:38 
2. Baerlocher K, Gitzelmann R, Nussli R, Dumermuth G 1971 Infantile lactic acidosis due to hereditary fructose 1,6-diphosphatase deficiency. Helv Paediatr Acta 26:489

3. Coude FX, Saudubray JM, DeMaugre F, Marsac C, Leroux JP 1978 Dichloroacetate as treatment for congenital lactic acidosis. N Engl J Med 299:1365

4. Crooks $J 1982$ Haemolytic jaundice in a neonate after intra-amniotic injection of methylene blue. Arch Dis Child 57:872

5. DeVivo DC, Hammond MW, Obert KA, Nelson JS, Pagliara AS 1979 Defective activation of the pyruvate dehydrogenase complex in subacute necrotizing encephalomyelopathy (Leigh's disease). Ann Neurol 6:483

6. DiMauro S, Mendell JR, Sahenk Z, Bashman D, Scarpa A, Scofield RM, Reiner C 1980 Fatal infantile mitochondrial myopathy and renal dysfunction due to cytochrome-C-oxidase deficiency. Neurology 30:795

7. Erickson RJ 1965 Familial infantile lactic acidosis. J Pediatr 66:1004

8. Falk RE, Cederbaum SD, Blau JP, Gibson GE, Mark RAP, Carrel RE 1976 Ketotic diet in management of pyruvate dehydrogenase deficiency. Pediatrics 58:713

9. Feldman GL, Wolf B 1979 Measurement of pyruvate carboxylase activity in amniotic fluid cells. Pediatr Res 14:153

10. Goodman LS, Gilman A 1975 The Pharmacological Basis of Therapeutics, fifth ed. 1979 MacMillan Co, Chicago, pp 1003-1004

11. Hansen TL, Christensen E 1979 Studies on pyruvate carboxylase from human fibroblasts and amniotic fluid cells. J Inher Metab Dis 2:23

12. Hartmann AF Sr, Wohlmann HJ, Purkerson ML, Wesley ME 1962 Lactate metabolism, studies of a child with a serious congenital deviation. $J$ Pediatr 61:165

13. Haworth JC, Perry TL, Hansen S 1974 Lactic acidosis due to a defect in pyruvate metabolism in 3 siblings. Pediatr Res $8: 433$

14. Hommes FA, Bendien K, Elema JD, Bremer HJ, Lombeck I 1976 Two case of phosphoenolpyruvate carboxykinase deficiency. Acta Paediatr Scand 65:233

15. Howell RR, Williams JC 1983 The glycogen storage diseases. In: Stanbury JB Wyngaarden JB, Fredrickson DS, Goldstein, JL, Brown MS (eds) The Metabolic Basis of Inherited Disease. McGraw-Hill, New York, pp 141-166

16. Howell RR, Ashton, DM, Wyngaarden JB 1962 Glucose-6-phosphatase deficiency glycogen storage disease. Pediatrics 29: 553
17. Israels S, Haworth JC, Dunn HG, Applegarth DA 1976 Lactic acidosis in childhood. Adv Pediatr 22:267

18. Lancaster G, Mamer OA, Scriver CR, Lamm P, Tjoa S 1974 Branched-chain$\alpha$-keto acids, isolated as oxime derivatives; relationship to the corresponding hydroxy acids and amino acids in maple syrup urine disease. Metabolism 23:257

19. Oliva PB 1970 Lactic acidosis. Am J Med 48:209

20. Raghunathan R, Russell JD, Arirec IJ 1977 Pyruvate carboxylase and phosphoenolpyruvate carboxylase in cultured human fibroblasts. $J$ Cell Physiol 92:285

21. Robinson BH, Taylor J, Sherwood WG 1980 The genetic heterogeneity of lactic acidosis: occurrence of recognizable inborn errors of metabolism in a pediatric population of lactic acidosis. Pediatr Res 14:956

22. Roth KS, Yang W, Allan L, Saunders M, Gravel R, Dakshinamurti K 1982 Prenatal administration of biotin in biotin responsive multiple carboxylase deficiency. Pediatr Res 16:126

23. Scriver CR, Mohyuddin F 1968 Amino acid transport in kidney: heterogeneity in AIB uptake. J Biol Chem 243:3207

24. Stromme JH, Borud O, Moe PJ 1976 Fatal lactic acidosis in a newborn attributable to a congeni.al defect of pyruvate dehydrogenase. Pediatr Res $10: 60$

25. Sweetman L 1981 Two forms of biotin-responsive multiple carboxylase deficiency. J Inher Metab Dis 4:53

26. Van Biervliet JPGM, Bruinis L, Ketting D, DeBree PK, Van DerHeiden C, Wadman SK, Bookelman H, Van Haelst U, Monnens LAH 1977 Mitochondrial myopathy with lactic acidemia, a DeToni-Fanconi-Debré syndrome, and a defective respiratory chain in voluntary striated muscles. Pediatr Res 11:1088

27. Vidailhet M, Lefebvre E, Beley G, Marsac C 1981 Neonatal lactic acidosis associated with pyruvate carboxylase deficiency. J Inher Metab Dis 4:131

28. Wick H, Scheizer K, Baumgartner R 1978 Thiamine dependency in a patient with congenital lactic acidemia due to pyruvate dehydrogenase deficiency. Agents Actions 7:405

29. Willems JL, Monnens LAH, Trybels JMF, Veerkamp JH, Meyer AEF, Van Dam K, Van Haelot U 1977 Leigh's encephalopathy in a patient with cytochrome oxidase deficiency in muscle tissue. Pediatrics 60:850

\title{
Oxidative Metabolism of Cord Blood Neutrophils: Relationship to Content and Degranulation of Cytoplasmic Granules
}

\author{
DANIEL R. AMBRUSO, BARBARA BENTWOOD, PETER M. HENSON, AND \\ RICHARD B. JOHNSTON, JR.
}

\section{Department of Pediatrics, The University of Colorado School of Medicine, National Jewish Hospital and} Research Center/National Asthma Center, and the Belle Bonfils Memorial Blood Center,

Denver, Colorado 80262

\begin{abstract}
Generation of oxygen metabolites is an important component of the neutrophil's armamentarium against microbes. Production of superoxide anion $\left(\mathrm{O}_{2}^{-}\right)$and generation of hydroxyl radical $(\cdot \mathrm{OH})$ were measured in neutrophils from cord blood of 12 vaginally delivered, term newborn infants and 12 adults after stimulation with phorbol myristate acetate (PMA) and opsonized zymosan. With either stimulus, generation of $\mathrm{OH}$ was relatively less than
\end{abstract}

Received March 1, 1983; accepted April 19, 1984.

Address reprints to Daniel R. Ambruso, M.D., Department of Pediatrics, University of Colorado Health Sciences Center (C-220), Denver, Colorado 80262.

These studies were supported by the Stacy True Memorial Fund and United States Public Health Service Grants AI 19423, AI 14148, AI 15853, and GM 24834. production of $\mathrm{O}_{2}^{-}$for all infants studied. This discrepancy might be related to abnormal release or diminished cell content of a cofactor necessary for production of $\mathrm{OH}$ from $\mathrm{O}_{2}^{-}$. Since both lactoferrin (LF) found in specific granules and myeloperoxidase (MPO) found in azurophilic granules have been shown to enhance $\mathrm{OH}$ generation, we compared degranulation of both granule types in response to PMA and opsonized zymosan and total neutrophil content of MPO, LF, and lysozyme in cord blood and adult neutrophils. Degranulation, even after pretreatment with cytochalasin B, was the same for newborn and adult neutrophils. Content of MPO was identical (adult, $204 \pm 24 A$ units, mean $\pm \operatorname{SEM}, n=9$; newborn, $201 \pm 21, n=9$ ) but lysozyme was mildly diminished (adults, $111 \pm 10 \mathrm{~A}$ units; 